\title{
Renal Pelvis and Ureter Cancer Pathologic Primary Tumor TNM Finding v8
}

National Cancer Institute

\section{Source}

National Cancer Institute. Renal Pelvis and Ureter Cancer Pathologic Primary Tumor

TNM Finding v8. NCI Thesaurus. Code C140339.

A pathologic finding about one or more characteristics of renal pelvis and ureter cancer, following the rules of the TNM AJCC v8 classification system as they pertain to staging of the primary tumor. 